Савчук Р. Стилістичні засоби у заголовках сучасних меліа текстів ...

УДК 81'38'23:070.433

DOI https://doi.org/10.24919/2308-4863/34-4-24

\author{
Руслана САВЧУК, \\ orcid.org/0000-0002-1431-9341 \\ кандидат філологічних наук, \\ доиент кафедри журналістики
}

Прикарпатського національного університету імені Василя Стефаника

(Івано-Франківськ, Україна) ruslana-savchuk@ukr.net

\title{
СТИЛІСТИЧНІ ЗАСОБИ У ЗАГОЛОВКАХ СУЧАСНИХ МЕДІАТЕКСТІВ: ПСИХОЛІНГВІСТИЧНИЙ АСПЕКТ
}

\begin{abstract}
У статті проаналізовано стилістичні засоби як психолінгвістичний фактор привернення уваги реципієнта до прочитання сучасного медіатексту.

Використано такі методи дослідження: описовий (інвентаризовано й систематизовано стилістичні засоби в заголовках сучасних мас-медіа), метод контекстуально-семантичного аналізу (розкрито змістове наповнення тропів і стилістичних фігур, виявлено їх психолінгвістичні особливості), метод компонентного аналізу (з'ясовано семні характеристики окремих лінгвоодиниць у складі тропів і стилістичних фігур). Метод експерименту (у формі анкетування) дав змогу визначити реакиіїреспондентів на стилістично марковані медіазаголовки.

Встановлено: продукування стилістичних засобів, щяо базуються переважно на неосмислових відношеннях (із перехрещенням психологічних і лінгвістичних вимірів), у заголовках сучасних засобів масової інформації спрямоване на досягнення максимальної ефективності мас-медійного континууму. Тропо-фігуральні конструкції як феномен мовної діяльності журналіста виступають не лише актуалізаторами виразності й конденсаторами інформативності, але й своєрідними вербальними «мотиваторами»- покликані стимулювати інтерес реципієнта, сприяти підвищенню читабельності публіцистичних матеріалів. Простежено, щуо стилістичні засоби в заголовкових комплексах новітніх засобів масової інформації апелюють до образного мислення та емоційного сприйняття адресата, вибудовують у його уяві нову систему асоиіативних зв'язків, розгортаючи глибинні семантичні параметри комунікативних відрізків. Закладені мовием аксіологічні (позитивно й негативно оцінні) категорії в тропо-фігуральних структурах сфокусовують читача на переосмислення інформації, деформування власних поглядів і ціннісних орієнтирів.

Визначено, що стилістичні засоби в заголовках сучасних мас-медіа є психолінгвістичним маркером впливу (виявлясться експліциттно й імпліųитно), адже, відбиваючи ставлення автора до висловленого й реалізуючи його ідейно-інтенціональні установки, зорієнтовують сприйняття та інтерпретацію тексту реципієнтом у заданому напрямі. Експериментальним матеріалом (результатами анкетування) підтверджено, щзо стилістично марковані медіазаголовки кониентрують увагу респондентів і мотивують до прочитання тексту.
\end{abstract}

Ключові слова: психолінгвістичний аспект, стилістичні засоби, заголовок, медіатекст, автор, реципієнт.

Ruslana SAVCHUK, orcid.org/0000-0002-1431-9341 Candidate of Philological Sciences, Associate Professor at the Department of Journalism Vasyl Stefanyk Precarpathian National University (Ivano-Frankivsk, Ukraine) ruslana-savchuk@ukr.net

\section{STYLISTIC MEANS IN THE HEADLINES OF CONTEMPORARY MEDIA TEXTS: THE PSYCHOLINGUISTIC ASPECT}

This article describes of the research is to analyze stylistic means found in the headlines of contemporary media as a psycholinguistic factor in attracting recipient's attention to reading a media text.

The following methods were used in the study: descriptive (stylistic means in the headlines of contemporary mass media were collected and systematized), context and semantic analysis (the semantic content of tropes and stylistic devices is determined, their psycholinguistic peculiarities are revealed), method of component analysis (seme characteristics of the language units consisting of tropes and stylistic devices are defined). The method of experiment (in the form of questionnaire) made it possible to determine the respondents' reactions to the stylistically marked media headlines.

Development of stylistic means based mainly on new meaning relations (with the intersection of psychological and linguistic dimensions) in the headlines of contemporary media texts is aimed at maximizing the effectiveness of the mass media continuum. It has been found out that tropes and stylistic devices, as a phenomenon of the journalist's linguistic activity, act not only as actualizers of expressiveness and informativeness, but also they are a kind of verbal 
«motivators», which are intended to stimulate the recipient's interest, to promote the readability of journalistic materials. Stylistic devices appeal to the imaginative thinking and emotional perception of the addressee and create a new system of associative communication in his or her imagination, expanding the deep semantic parameters of communicative segments. The axiological (with positive and negative evaluation) categories laid out by the speaker in the tropes and stylistic devices of the analyzed media headlines focus the reader on rethinking information, deforming one's own views and values.

The stylistic means in the headlines of contemporary mass media are a psycholinguistic marker of influence (manifested explicitly and implicitly), because, reflecting the author's attitude to the expressed information and realizing his or her ideological and intentional positions, these means orient the perception and interpretation of the text in a given direction. The experimental material (the results of the questionnaire) confirmed that the stylistically marked media headlines attract the attention of the respondents and motivate them to read the text.

Key words: psycholinguistic aspect, stylistic means, headline, media text, author, recipient.

Постановка проблеми. Одним 3 актуальних завдань сучасного антропозорієнтованого мовознавства $є$ вивчення медіатексту в проєкції різних наукових підходів - комунікативно-прагматичного, синергетичного, когнітивно-семіотичного, аксіологічного, соціокультурного, психолінгвістичного. Кожна з окреслених парадигм дає змогу проаналізувати доцільність використання певних мовних одиниць у текстовому континуумі, окреслити особливості їх функціонування та взаємодії, дешифрувати латентні значеннєві параметри, прагматичні конотації, визначити оцінно-експресивну значущість, специфіку продукування лексем (неономінацій) і закономірності їх сприйняття.

Аналіз досліджень. Питання тексту крізь призму психолінгвістики порушено в наукових працях багатьох вітчизняних і зарубіжних дослідників, що дає змогу глибше розкрити проблеми мовної свідомості, сприймання (осмислення) та розуміння (інтерпретацію) реципієнтом комунікативного повідомлення (Белянин, 2000; Засєкіна, Засєкін, 2008; Леонтьев, 1997; Селіванова, 2008; Холод, 2011), виявити основні фактори мовленнєвого впливу на адресата (Леонтьев, 1997), пізнати чіткий взаємозв'язок елементів у системі «автор - авторська проєкція тексту тіло тексту - реципієнт - проєкція тексту в реципієнта» (Залевская, 2005) тощо.

Психолінгвістичні особливості українського новітнього медійного континууму 3 акцентом на «психологічну зумовленість мовних одиниць» (Куранова, 2012) та їх впливову функцію викладено в окремих дослідницьких розвідках. Важливим у цьому ракурсі $\epsilon$ розгляд лексики з пейоративним значенням у друкованих засобах масової інформації (далі - ЗМІ) - авторських неологізмів та інновацій іншомовного походження, медичної термінології, молодіжних жаргонізмів, суржикізмів (Навальна, 2017); структурно-дериваційних ознак новотворів, які употужнюють головні наміри інформаційних повідомлень, підвищують градус напруження, залишають емоційний відбиток (позитивний чи негативний) у свідомості адресата (Межов, Костусяк, 2018: 107); маніпулятивного потенціалу парадоксальних висловів (Стехіна, 2010), перифраз та евфемізмів у мові ЗМІ (Булах, 2015). Д. Ю. Сизонов здійснив аналіз медійних текстів із вказівкою на екстра- й інтралінгвальні чинники, визначивши «основні стратегії та тактики з психо- й медіалінгвістичного боку, що впливають на медіаграмотність українських реципієнтів (маніпуляція, вплив, оцінність та уникнення конфліктності)» (Сизонов, 2017: 87). Усі ці й багато інших праць засвідчують: сучасні журналісти використовують цілий арсенал методів і прийомів психологічного впливу на свідомість (підсвідомість) індивіда 3 метою стимулювання очікуваних емоційних реакцій, трансформації чи формування стереотипних уявлень (зумовлених конструюванням нової реальності), зміни поведінкових модусів. Незважаючи на те, що окремі плани стилістичних маркерів у мові мас-медіа уже розглянуто, психолінгвістичний потенціал тропофігуральних конструкцій залишається актуальним для вивчення.

Мета статті - проаналізувати стилістичні засоби як психолінгвістичний фактор привернення уваги реципієнта до прочитання медіатексту. Поставлена мета передбачає виконання таких завдань: визначити найпоширеніші тропофігуральні структури в заголовкових комплексах сучасних інтернет-видань, зокрема з'ясувати їх психолінгвістичні особливості; простежити реакцію респондентів (потенційних читачів) на медіазаголовки, маніфестовані тропами й стилістичними фігурами.

Для досягнення сформульованої мети й виконання завдань використано такі методи дослідження: описовий (для інвентаризації та систематизації стилістичних засобів, зафіксованих у заголовкових комплексах новітніх інтернет3МI), метод контекстуально-семантичного аналізу (для встановлення змістового наповнення тропів і стилістичних фігур, виявлення їх психолінгвістичного потенціалу), частково - метод компонентного аналізу (спрямований на роз- 
криття семних характеристик окремих мовних одиниць у тропеїчних i фігуральних конструкціях), метод експерименту (у формі анкетування - для з'ясування реакції респондентів на медіазаголовки, вербалізовані тропо-фігуральними структурами).

Фактичним матеріалом обрано назви текстів регіональних електронних 3MI: «Бартка»- bartka. com.ua, «Bерсіï» - versii.if.ua, «Вікна»-vikna.if.ua, «Галицький кореспондент»-gk-press.if.ua, «Галичина»-galychyna.if.ua, «Місто»-mi100.info, «Репортер» - report.if.ua (публікації за 2018-2020 роки).

Виклад основного матеріалу. Пріоритетом для мас-медійного тексту XXI століття є привернення уваги масового адресата, інтенсифікація впливу на суспільну свідомість - переорієнтування думок та уявлень цільової аудиторії в русло комунікативно-прагматичних, світоглядно-аксіологічних настанов автора, тобто досягнення запланованого перлокутивного ефекту. Учені кваліфікують медіатекст як «продукт журналістської творчості» (Яцимірська, Драган, 2007: 267), тобто феномен креативної мовної особистості з урахуванням психологічних факторів. За визначенням Л. В. Засєкіної та С. В. Засєкіна, мовна особистість - це «сукупність пізнавальних, емоційних i мотиваційних властивостей, що забезпечують мовну компетенцію людини як носія певного національно-культурного простору» (Засєкіна, Засєкін, 2008: 22).

На наш погляд, одним 3 основних інструментів залучення потенційного адресата на сторону автора (журналіста) є включення мотиваційних установок у мас-медійний текстовий континуум. У психології мотивацію розглядають як «сукупність стійких мотивів, спонукань, що визначають зміст, спрямованість і характер діяльності людини, iii поведінку» (Синявський, Сергєєнкова, 2007).

Вдалою площиною для реалізації мотиваційно-спонукальної смислової програми комунікатора виступають заголовкові комплекси, адже від «правильного» номінування тексту залежатимуть погляди, емоції, зацікавлення, вподобання, ціннісні орієнтири адресата, а головне - чи буде прочитаним журналістський матеріал. Влучне оформлення назви в такому контексті трактуємо насамперед як уміння автора виявити свій інтелектуально-креативний потенціал, завуалювавши різнорівневими мовними знаками (унікальною сполучуваністю лінгвоодиниць) стратегічні ходи й тактики, рекомендаційні формулювання, прагматичні інтенції.

Як засвідчує фактичний матеріал проведеного дослідження, саме продукування тропо-фігуральних конструкцій (зумовлене оригінальним моделюванням реальності, асоціативно-образними мисленнєвими кодами мовця) забезпечує ефективність мас-медійного дискурсу. Стилістичні засоби - своєрідні вербальні «мотиватори», покликані стимулювати інтерес адресата до прочитання публіцистичних матеріалів.

Домінантами в конструюванні аналізованих текстів-заголовків означено тропеїчні моделі, які в нестандартній формі експлікують авторський (ідіосмисловий) варіант репрезентації дійсності. Процес метафоризації дослідники тлумачать не лише як мовний, а й психічний феномен особистості (Borbely, 1998; Gibbs, 2002). Медійні метафоричні структури апелюють до образного мислення та емоційного сприйняття реципієнта, вибудовують у його уяві нову систему асоціативних зв’язків. Порівняймо назви інформаційних статей із газетної рубрики «Культура»: «Поезія з ароматом кави, або Як поет Богдан Томенчук «заварив» одразу «Дві джезви» віриів» («Галичина», 21.11.2019) - у контексті простежуємо семантичні паралелі (умовне зближення): поет (володіє мистецтвом слова) - бариста (володіє мистецтвом приготування кави); вірші - кава; «написав» - «заварив»; «Ритмомелодика ж⿻иттевих доріг. Любомир Михайлів прийшов до читачів із поетичною збіркою «Карпати, Карnати...» («Галичина», 25.11.2019) - журналіст акцентує: поезія як віддзеркалення життя (життєвого досвіду письменника), що має свій особливий ритм і мелодику. Наведені метафори надають заголовкам унікальності й динамізму, розгортають змістові параметри комунікативних відрізків. Головна їх мета - активізувати читацьку увагу, вплинути на емоційний фон реципієнта, закарбуватися в пам'яті. Водночас поетизація медійних заголовків, реалізована нешаблонним сполученням мовних елементів, смисловим паралелізмом, приводить до інтригування чи навіть дезорієнтації адресата - перед ним постає дилема: цитата чи слова журналіста? Це й спонукає читача шукати відповідь-розгадку в тексті статті.

Метафори - епіцентр згущення думок автора, виразники його психологічного стану. Вони виступають репрезентантами суб'єктивно-модального ставлення мас-медійника до повідомлюваних фактів, що часто виливається в критику влади, політики, судової системи, неефективності законів і реформ тощо. Усе це сприяє формуванню відповідної позиції та оцінки в сприйняттєвій сфері реципієнта. Найчастіше метафоричні моделі, зафіксовані в заголовках 3МI, містять аксіологічні установки, прагматичний потенціал яких спрямований на відбиття негативних фрагментів окрес- 
леної реальності: «Пантеон мерських обіцянок» («Місто», 26.09.2018) - статистика виконаних і невиконаних обіцянок очільників міста; «Будова 3 присмаком обману» («Галицький кореспондент», 28.04.2018) - викладення проблеми незаконного будівництва; «Кладовище автомобілів: на кордоні «євробляхи» розбирають на запчастини» («Галицький кореспондент», 30.11.2018) - засудження ліквідації законів, які надавали можливість українцям завозити автомобілі з іноземною реєстрацією в режимі транзиту; «Газові тарифні гойдалки» («Галичина», 07.06.2019) - міркування про позитивні й негативні сторони нової формули розрахунку ціни на газ для населення; «ціна» суддівської печатки» («Місто», 12.06.2019) - окреслення проблемних питань: корупція в судовій системі, суддівська бюрократія, панування канцелярської радянської риторики тощо (в контексті стрижневе поняття «ціна» конденсує полярні семи - «вартість» і «цінність»).

Як показав матеріал дослідження, відправною точкою до асоціативних слайдів у свідомості реципієнта $є$ також персоніфіковані конструкції, сформовані на основі почуттєво-психологічних факторів мовця. Вони транслюють прагматичноаксіологічний зміст повідомлення, сприяють підкресленню ключових принципів тексту, підпорядкованих насамперед психолінгвістичному впливу на адресата. Комунікатор, антропоморфізуючи стрижневі образи - реалії навколишньої дійсності, намагається сфокусувати увагу читача на порушених проблемах, активізувати його емоційну систему й викликати емпатичну реакцію на висловлене: «Музей історії в селищі Делятині переживає дуже скрутні часи й ледь дихає) («Галичина», 26.06.2019) - акцентовано на необхідності не лише капітального відновлення музейного приміщення, але й збереження та підтримки музейної справи; «Коли мости плачуть. 90\% переправ на Прикарпатті потребують ремонту» («Репортер», 27.08.2019) - припинення реконструкції мостових споруд через недофінансування (призводить до нещасних випадків на дорогах); «Диістер вимагає поваги. Як Гірський рятувальний центр бореться зі сміттям» («Репортер», 06.12.2019) - окреслено питання бережного ставлення до природи (люди повинні відповідати за недотримання правил природокористування); «Дерева помиратимуть онлайн. Чи допоможе електронний облік знизити вирубку лісів» («Репортер», 13.11.2019) - висловлено побоювання в дієвості сучасних методів протидії незаконним рубкам лісів і запобігання тіньового обігу деревини в Україні.
Тропеїчні засоби концентрують додаткові (латентні) нарощення семантичного плану, служать аксіопсихологічними кваліфікаційними лінгвоструктурами, експлікаторами когнітивних зусиль мовця. Впливовий ефект на адресата в заголовках аналізованих інтернет-3МІ здійснюють:

a) епітетні конструкції - характеризують фрагменти реальності, часто містять конотативне (оцінне) навантаження, породжуючи низку асоціацій у свідомості читача: «Тепле» житло зростає у вартості» («Вікна», 13.10.2019) - «тепле» вжито в значенні «енергомодернізоване»; «Micтичний Франківськ» («Місто», 16.07.2018) - містить асоціати «надприродний», «потойбічний» (місто 3 аномальною енергетикою); «Пекельна ніч y Bорохті» («Галицький кореспондент», 15.02.2020) - в означенні закладено семи «пекло», «жах» (автор інформує про страшні наслідки пожежі); «Прикрий периий дзвоник» («Галицький кореспондент», 08.09.2019) - епітет вказує на негативні емоції, пов'язані з першим днем навчального року (текст статті сигналізує: під час урочистостей порушенням громадського спокою стала звістка про реорганізацію місцевого навчального закладу);

б) порівняння - зближення / ототожнення реалій базується на асоціативній схожості чи продиктоване авторським досвідом, які насправді є віддаленими (зв'язок між суб'єктом та об'єктом компаративної моделі виникає тільки в уяві номінатора): «Коли пісня, як дихання» («Галичина», 22.09.2018) - вказівка на невіддільну роль пісні в житті людини (в назві закодований глибший смисл: пісенність - надважливий складник духовного й культурного життя українського народу); «“Очі, як вишні в росі”: які компліменти говорили колись українці〉 («Бартка», 25.08.2019) компаративема засвідчує унікальність народного світогляду, водночас сконцентровує на паралельній інтерпретації (з урахуванням поетичного символізму): очі - краса, роса - сльози (чуттєвість, драматизм як константи українського фольклору); «Micm-nривид» («Галицький кореспондент», 06.05.2018) - лінгвоструктура проєктує семи: «оманливий», «нереальний»; у тексті дерев'яна конструкція, яка офіційно не задокументована; «Будинок-рукавичка. Як у Франківську «кидають» покупців квартир» («Репортер», 07.03.2020) - асоціати: «тісний», «переповнений» (компаративема розкриває інтертекстуальні рефлексії - читач згадує казку про рукавичку); основне смислове навантаження фокусує сленгізм «кинути» (обманути): в публікації йдеться про афери, пов'язані з продажем квартир; 
в) перифрази - у свідомості реципієнта корелюють із певною ознакою референта, однак часто містять контекстуальні (індивідуально-авторські) конотації, що порушує їхню спільність iз денотатом, вербалізуючи нові мислеобрази: «Божий вогонь» - найкращий лік для гіпертоніків» («Галичина», 15.10.2018) - із тексту статті дешифруємо: «Божим вогнем» (переклад із латинської мови) давні римляни називали хурму; найменування «найкращий лік» пояснюється наявністю в тропічному плоді лікувальних властивостей; «Електричка на колесах» («Місто», 08.02.2019) - електромобіль; «Кам'яні обличчя Франківська. Що таке маскарони ци чому їх треба рятувати» («Репортер», 03.12.2019) скульптурні прикраси у вигляді голови людини, тварини, міфічної істоти; «Франківський Рокі» («Місто», 24.06.2018) - місцевий боксер; «Український Джееймс Бонд: історія про розвідника, котрий був шпигуном п'яти ворожсих між собою розвідок» («Версії», 02.01.2020) - австрійський та український військовий і політичний діяч Ріко (Ріхард) Ярий. Отже, наведені тропеїчні засоби, що базуються переважно на неосемантичних відношеннях, у заголовкових комплексах скеровують повідомлення в необхідний для журналіста комунікативно-прагматичний ракурс.

Серед перифрастичних номінацій, зафіксованих у назвах аналізованих інтернет-видань, варто виокремити й аксіологічно марковані (зумовлені суб'єктивно-оцінною установкою журналіста) - зі знаком «+»: «Місто позитивних змін» («Галичина», 26.12.2019), «Місто флірту й театру, місто тречності й сентиментів: чого не вистачає в Івано-Франківську» («Місто», 08.07.2018) - синонімічні перифрази уможливлюють різнопланове розкриття актуалізованого образу (міста Івано-Франківськ); «Франківська малеча разом з Пряничною Феєю створила солодких совенят» («Місто», 18.11.2019) - названо майстриню, яка виготовляє і розписує пряники; зі знаком «-»: «Горе край дороги. Про щз можуть розповісти мозаїки на зупинках у селах Прикарnаття» («Бартка», 03.11.2019) - контекстуальна номінація сигналізує про занедбаність мозаїчних зупинок; «Лісоруб «в законі». Що відомо про першого новопризначеного «зеленого» голову РДА на Прикарпатті?» («Версії», 08.11.2019). Закладені мовцем позитивно й негативно оцінні параметри повідомлення здатні спровокувати читача до переосмислення інформації, деформування власних поглядів і ціннісних оріснтирів. Однак аксіологічна шкала в розумінні адресанта й адресата може бути різною, що пояснюється рівнем пресупозиційних знань, певними психологічними чинниками, зокрема індивідуальними моделями сприймання та оцінювання дійсності.

Зупинимося детальніше на останньому проілюстрованому заголовку.

Мас-медійник використовує пунктуаційний знак для акцентування уваги на стрижневих лексемах у назві тексту -лісоруб «в законі», «зелений» голова РДА. Трансформація відомого словосполучення «злодій у законі», відсилаючи реципієнта до фонової інформації, викликає відповідні емоції, пов'язані зі сприйняттям цього негативного явища в житті суспільства. Виразну аксіологічну ідентифікацію містить і внутрішня форма слова лісоруб - «той, що рубає ліс», у контексті дорівнює трактуванню «той, що завдає шкоди лісові». У публікації йдеться про головного лісничого, який неодноразово потрапляв у різні конфліктні ситуації, пов’язані з вирубкою лісу.

Ключова лексема «зелений» у текстовому сегменті актуалізує такі семантичні координати: 1) який не має досвіду в політиці; тлумачний словник фіксує: слово вживається в переносному, розмовному значенні - «який не має життєвого досвіду; недосвідчений» (Бусел, 2005: 456); 2) кольорономінант - вказівка на приналежність до партії «Слуга народу».

Таким чином, розділовий знак (лапки) й заміна мовного компонента (трансформація) в складі перифрази роблять представлений заголовок виразнішим для сприймання, закріплюючи у свідомості реципієнта новий асоціативний ряд.

Окрім тропів, у досліджуваних 3МІ спостерігаємо функціонування стилістичних фігур, які також продукують «свіжі» смислові ракурси 3 метою інтенсифікації психологічного впливу на читача:

a) антитеза - опозиційні контекстуально зумовлені лінгвоодиниці розхитують психоемоційний фон адресата, стаючи імпульсами до певної позиції - співпереживання, обурення, зацікавлення, роздуму: «Врятувати сина-втратити ж⿻тлло («Галицький кореспондент», 09.01.2019); «Діти є - шкіл у Франківську немає» («Місто», 01.01.2019); «Менше витрачати $u$ більше заробляти. Оприлюднено план оптимізації Калуської стоматполіклініки» («Вікна», 01.09.2019); «Абстрактне мистецтвво в ІваноФранківську: тиха гавань чи бурхливе море» («Галичина», 10.07.2019);

б) оксиморон - сприйняття логічно непоєднуваних мовних конструкцій спочатку формує враження незрозумілості, відчуття внутрішньої суперечливості, пізніше (зі зверненням до тексту статті) - новий ракурс осмислення позначува- 
ного; акумулювання несподіваних асоціацій служить сприятливим тлом для фокусування уваги реципієнта: «Цілюща отрута» («Галицький кореспондент», 21.10.2018) - про народне лікування зміїною настоянкою; «Політичні важковаговики, нові «старі» обличчя та кандидатиаутсайдери: хто на Прикарпатті бореться за депутатський мандат» («Версії», 27.06.2019) журналіст подає перелік кандидатів у депутати, де «новими «старими» обличчями іменує політиків, які вже неодноразово виконували обов'язки представників народу; «Нещасна доля «Щасливої Аравї̈» («Місто», 11.03.2018) - «Щасливою Аравією» давньоримські географи назвали Ємен (у перекладі з арабської мови означає «щастя», «благоденство»), однак у сучасному світі цю країну визнано найнебезпечнішою для проживання через війну, голод і хвороби;

в) парадокс - актуалізує контрастність, полярність смислових відношень у межах контексту (як антитеза й оксиморон), реалізуючи ефект непередбачуваності, тобто «ефект обманутого очікування» (Селіванова, 2008: 221), що призводить до суперечностей пресупозиційних знань читача; водночас комунікативна оригінальність (незаштампованість викладу інформації), зумовлена авторськими прагматичними інтенціями, сприяє зосередженню уваги реципієнта, приводить до інтригування: «Індійський Донбас» («Місто», 26.01.2020) - журналіст порівнює ситуацію в Кашмірі зі сценарієм Донбасу (йдеться про особливі умови їх перебування в складі держав); «Провокація, а не реставрація» («Місто», 15.08.2018) - порушено проблему знищення історичних пам'яток міста; «Конкурс без конкурсу. У Калуші визначили перевізників на найближчих n'ять років» («Вікна», 17.05.2019) - недотримання конкурсних вимог;

г) парономазія - один із видів креативного самовираження автора; базується на «обіграванні» ключових слів, виступає своєрідним емоційним центром у заголовкових комплексах, сконцентровує на провідній думці висловленого: «Угода без згоди. Що зміниться, якщо нардепи проголосують новий закон «Про праиюю» («Репортер», 28.01.2020); «Банки чи «баньки»? Як зберігають гроші депутати міської ради Івано-Франківська» («Місто», 29.10.2018) - «банька» (розмовний варіант слова «банка») - скляна посудина; «До Долини - на уродини: у день свого 1040-річчя місто нафтовиків дивувало, захоплювало й веселило» («Галичина», 29.08.2019);

г) рима (римування) - служить для створення гумористичного ефекту, іронічності, однак осно- вна мета - зорієнтувати адресата на сприйняття імпліцитного змісту повідомлення: «Напустив туману, поӥхав до Оману» - українські соимережі про Зеленського» («Версії», 06.01.2020) реагування на мету й статус поїздки президента; «Прикарпатський нардеп Анатолій Дирів: xата - y тата, фірма - у брата?» («Місто», 26.04.2018) - вказівка на задекларовані й незадекларовані доходи депутата; «У Франківську добрі люди - на дорогу завжди буде» («Місто», 14.04.2019) - у статті автор з'ясовує, кому готові допомогти люди, якщо загальновідомо: жебракування - це бізнес;

д) замовчування - пропуски слів, словосполучень чи речень стимулюють до вдумливого осмислення інформації, надають можливість читачеві сформувати власну думку, ініціюють до заповнення текстових лакун через відсилання до фонових знань: «Іловайськ 2014. Вижити... Стати героєм» («Галичина», 02.09.2019); «Люди, імені яких... Ще трохи із життя пам'ятників і вулиць Івано-Франківська» («Репортер», 30.09.2019); «Віщий Олег, князь... «Московський», або Як першого українського «правителя семи всесвітів» просувають у Росії на роль засновника столиці $P \Phi »$ («Галичина», 10.01.2020);

е) риторичні запитання - апелюють до емоційної сфери адресата, виявляючи роль своєрідних психологічних маніпуляторів, викликають інтерес, спонукають до розмірковування (порівняння та зіставлення різних думок / фактів): «Чоловік у декреті: норма чи екзотика?» («Місто», 20.03.2018), «П'ятниия-розпусниия та пиво щзодня - зняття стресу чи явний алкоголізм?» («Версії», 27.09.2019), «Нетверезі безхатьки: проблема лікарень чи всього міста?» («Місто», 13.04.2019); провокують до дії: «A ти вже придбав квитки на улюблені заходи?» («Галицький кореспондент», 30.05.2019). Інтенсифікаторами уваги реципієнта можна окреслити питальні слова в складі заголовкової риторичної фігури. Такі лінгвоконструкції, зумовлені психологічними установками, «роблять» читача активним учасником комунікативного акту, залучають його до пошуку відповіді, а головне - «змушують» прочитати журналістський матеріал і відреагувати на повідомлюване: «Хто й за скільки купив Калуш?» («Вікна», 27.04.2018) - у тексті йдеться про розпродаж приміщень комунальної власності; «Скільки «коштують» прикарпатські нардепи?» («Місто», 23.01.2019); «Скільки коштує україниям «бабуся»?» («Місто», 02.10.2018) - у статті «бабуся» - соціальний образ (так автор найменує одержувачів пільг і субсидій). 
Як бачимо, тропи й стилістичні фігури в назвах журналістських матеріалів $є$ психолінгвістичними маркерами впливу (виявляються експліцитно й латентно), реалізують прагматичні смислові плани автора, координують сприйняття та інтерпретацію тексту адресатом у потрібному напрямі.

Результати експериментального дослідження. Аналіз фактичного матеріалу дав підстави висловити гіпотезу: саме стилістично марковані медіазаголовки, вербалізовані тропофігуральними конструкціями, виступають актуалізаторами уваги реципієнтів, мотиваційними імпульсами до прочитання тексту.

Для підтвердження чи спростування нашої гіпотези було проведено експеримент у формі анкетування (анкета $A$ - запитання, анкети $\overline{~ т а ~}$ $B$ - завдання). Учасники експерименту: студенти, викладачі й працівники одного із закладів вищої освіти м. Івано-Франківська. Оскільки респонденти в анкеті вказували свій вік, їх умовно поділено на 2 групи: 1 група - 18-25 років, 2 група 26-40 років (кількість осіб у кожній групі - 50, загальна кількість опитаних - 100).

Запитання анкети A дозволило 3'ясувати, 3 яких джерел респонденти найчастіше дізнаються інформацію - 3 друкованих чи електронних 3МI.

За результатами анкети $A$ (рис.1.) виявлено: учасники експерименту надають перевагу електронним джерелам: 50 осіб вікової категорії $18-25$ років (100\%) та 48 осіб - 26-40 років $(96 \%)$; до друкованоїпресинайчастішезвертаються тільки двоє осіб із вікової категорії $26-40$ років (4\%).

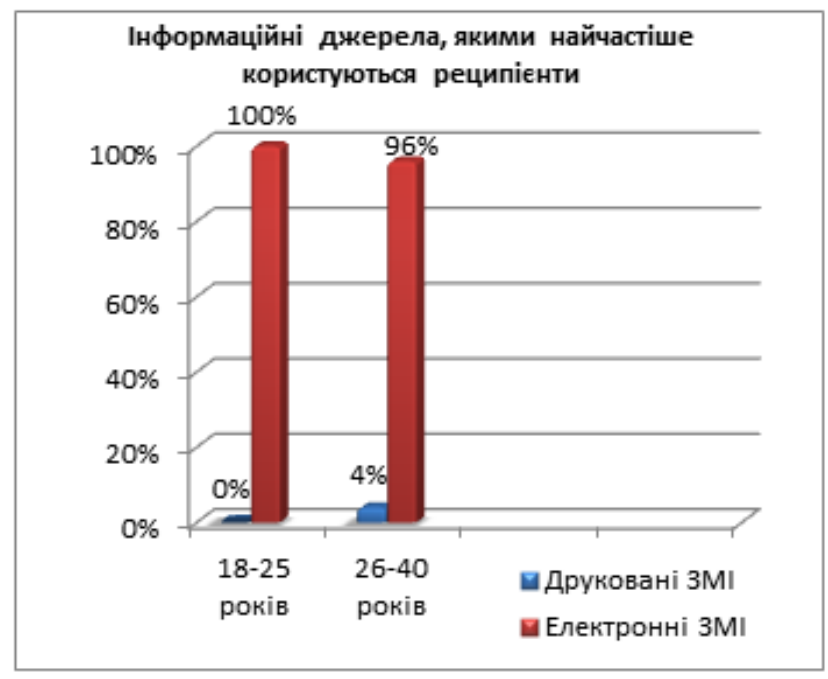

Рис. 1. Інформаційні джерела, якими найчастіше користуються реципіснти

В анкеті $Б$ респондентам було запропоновано 8 блоків медіазаголовків із різних рубрик періодики. Зазначимо, що деякі назви текстів виписано
3 інтернет-3МІ (без указівки на джерело). Кожен блок представлений двома назвами: А) стилістично нейтральний заголовок; Б) стилістично маркований заголовок (містить тропо-фігуральні конструкції). Респонденти повинні були вказати той варіант назви тексту, який привернув їхню увагу (зацікавив), тобто спонукав прочитати статтю.

Результати анкетування (рис.1, 2) засвідчили такі фактичні дані:

Блок 1: А. «Міська влада визнала незадовільною роботу АT «Оріана» - 15 осіб (18-25 років, 30\%), 17 осіб (26-40 років, 34\%). Б. «Міська влада показала керівництву «Оріани» червону картку»35 осіб (18-25 років, 70\%), 33 особи (26-40 років, $66 \%)$.

Блок 2: А. «У Рогатині відбудеться ще один фестиваль» - тільки 1 особа (18-25 років, 2\%), 3 особи (26-40 років, 6\%). Б. «Малі міста великі враження: Рогатин здивує щее одним фестивалем» - 49 осіб (18-25 років, 98\%), 47 осіб (26-40 років, 94\%).

Блок 3: А. «Забезпечення організаиії пасажирських перевезень на території області» - 4 особи (18-25 років, 8\%), 16 осіб (26-40 років, 32\%). Б. «Ринок пасажирських маршрутів: виживає сильніший» - 46 осіб (18-25 років, 92\%), 34 особи (26-40 років, 68\%).

Блок 4: А. "Найчастіше магазинних злодїв ловлять завдяки відеокамерам» - 13 осіб (18-25 років, 26\%), 19 осіб (26-40 років, 38\%). Б. «Ковбаса до рукава приросла» - 37 осіб (18-25 років, 74\%), 31 особа (26-40 років, 62\%).

Блок 5: А. «В Івано-Франківську відбудеться виставка місиевої художнииі Світлани Хміль» - 22 особи (18-25 років, 44\%), 23 особи (26-40 років, 46\%). Б. «Мистецтвом дихає Франківськ!» - 28 осіб (18-25 років, 56\%), 27 осіб (26-40 років, $54 \%$ ).

Блок 6: А. «В Івано-Франківську відкрили ковану скульптуру «Мої птахи» - 10 осіб (18-25 років, 20\%), 15 осіб (26-40 років, 30\%). Б. «Подарунок ковалів: до Івано-Франківська прилетіли металеві птахи» - 40 осіб (18-25 років, $80 \%), 35$ осіб (26-40 років, $70 \%$ ).

Блок 7: А. «Як законно повернути частину кочтів за навчання» - 13 осіб (18-25 років, 26\%), 22 особи (26-40 років, 44\%). Б. «Кешбек під ялинку» - 37 осіб (18-25 років, 74\%), 28 осіб (26-40 років, 56\%).

Блок 8: А. «Прикордонники виявили в мікроавтобусі вітаміни для спортсменів» - 9 осіб (18-25 років, 18\%), 13 осіб (26-40 років, 26\%). Б. «Енергетична контрабанда» - 41 особа (18-25 років, 82\%), 37 осіб (26-40 років, 74\%). 


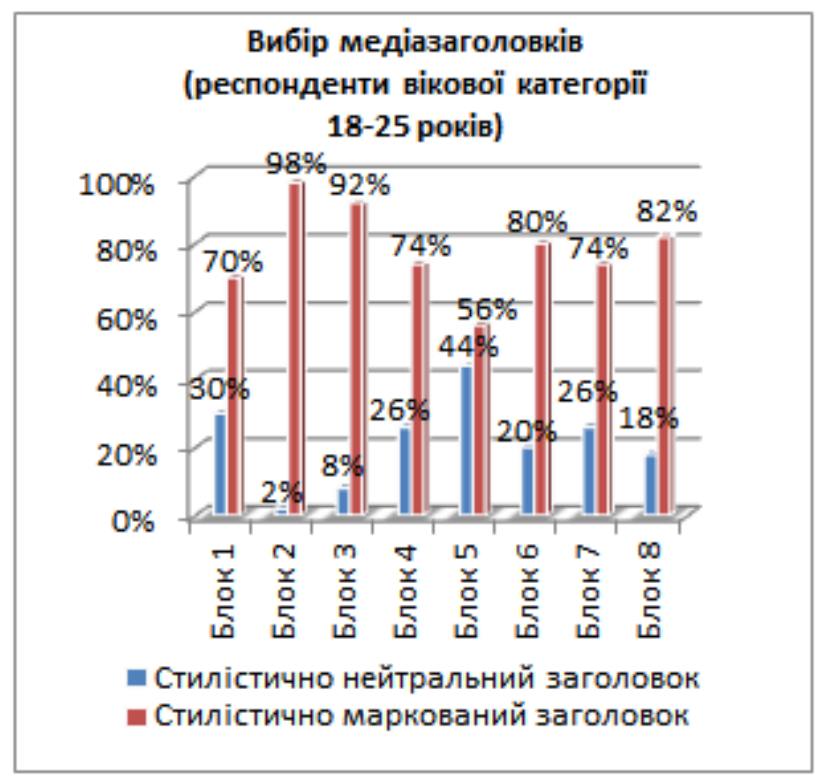

Рис. 2. Вибір медіазаголовків (респонденти вікової категорії 18-25 років)

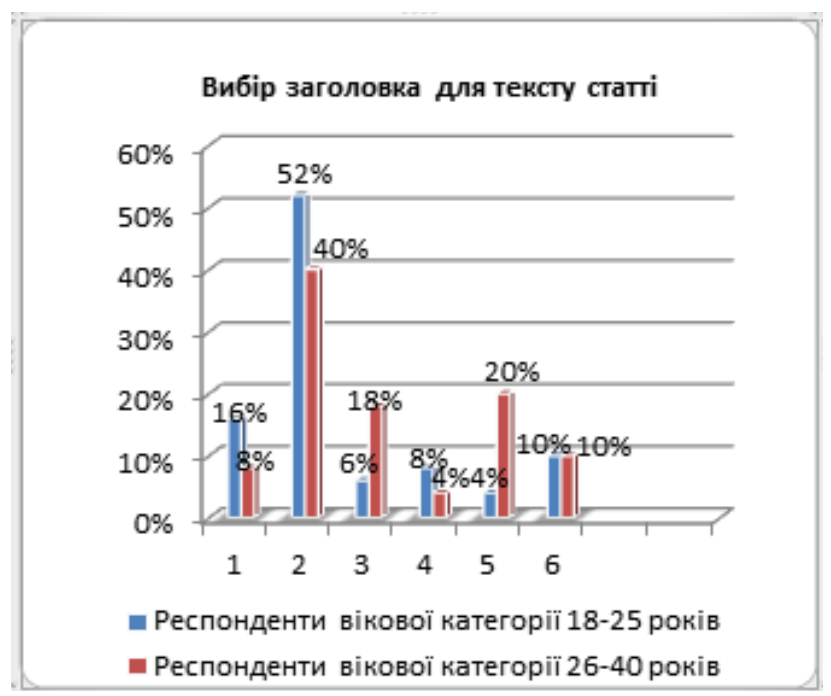

Рис. 4. Вибір заголовка для тексту статті

Таким чином, стилістично навантажені заголовкові комплекси привернули увагу більшості опитаних. Ймовірно, це пов'язано з тим, що свідомість людини запрограмована на постійний розвиток, а заштамповані фрази вже не викликають зацікавлення, адже сигналізують про відоме й зрозуміле. I навпаки - якщо заголовок креативний, маніфестований тропеїчними й фігуральними засобами, то свідомість сприйматиме інформацію як нову.

В анкеті $B$ респондентам запропоновано текст статті (2 759 знаків, 427 слів), який викладає тему пограбування (в інформаційному матеріалі акцентовано: грабіжник залишав солодощі як «компенсацію» за пограбовані фінансові установи), а також представлено 6 варіантів заголовків (деякі сконструйовано $з$ урахуванням психолінгвістич-

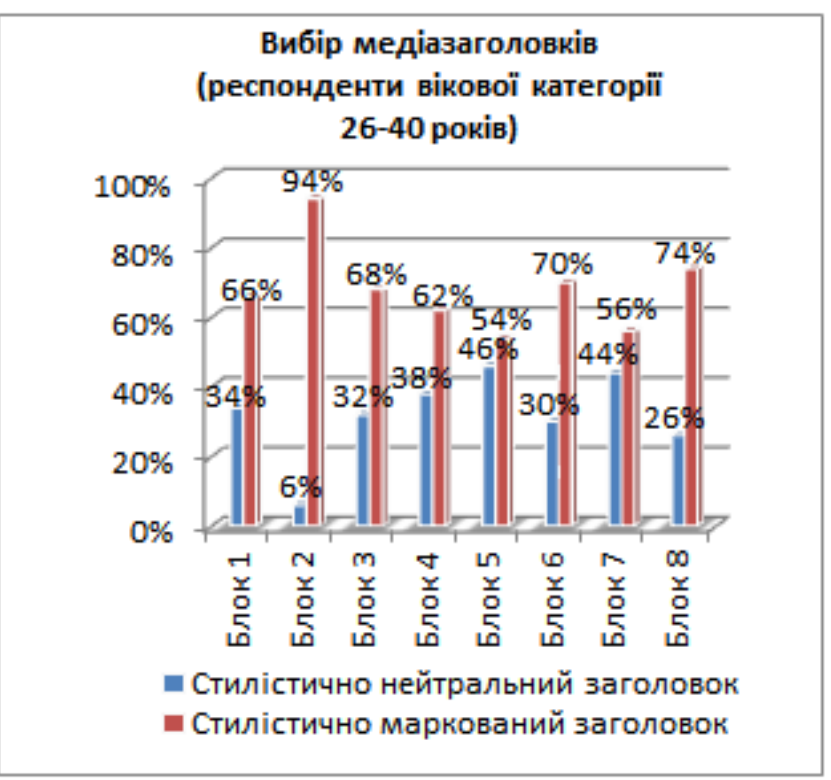

Рис. 3. Вибір медіазаголовків

(респонденти вікової категорії 26-40 років)

ного аспекту). Учасники експерименту повинні були спочатку прочитати медіатекст, а потім вибрати назву, яка, на їхню думку, відбиває суть повідомлення, тобто асоціюється зі змістом статті.

Результати опитування (рис. 4) водночас дали змогу простежити психологічну реакцію деяких реципієнтів на сприйняття інформації (засуджують чи виправдовують грабіжника), що фіксується вибором окремих запропонованих заголовків (позначено й квадратних дужках): 1. «3a гріх солодощами не відкупишся» [засудження] -8 осіб (18-25 років, 16\%), 4 особи (26-40 років, 8\%). 2. «Солодкий грабіжник» - 28 осіб (18-25 років, 52\%), 20 осіб (26-40 років, 40\%). 3. «Уродженець Прикарпаття обікрав банк»-3 особи (18-25 років, 6\%), 9 осіб (26-40 років, 18\%). 4. «Що залишив грабіжник?» - 4 особи (18-25 років, 8\%), 2 особи (26-40 років, 4\%). 5. «Грабував награбоване» [виправдання] - 2 особи (18-25 років, 4\%), 10 осіб (26-40 років, 20\%). 6. «Щастя не в грошах» [виправдання] - 5 осіб (18-25 років, 10\%), 5 осіб (26-40 років, 10\%). Зазначимо й те, що серед проілюстрованих заголовків лідирує стилістично забарвлений («Солодкий грабіжник»), якому надали перевагу $52 \%$ респондентів вікової категорії $18-25$ років і $40 \%$ - вікової категорії 26-40 років.

Отже, загальні результати експерименту підтверджують нашу гіпотезу.

Висновки. Матеріал проведеного дослідження дає підстави стверджувати, що стилістичні засоби, зафіксовані в заголовкових комплексах сучасних 3MI, справді є психолінгвістичними маркерами: 
впливають на свідомість (підсвідомість) реципієнта, скеровують його думки, погляди в напрям авторських комунікативно-прагматичних інтенцій. Репрезентантами креативного самовираження журналіста в аналізованих найменуваннях медійних текстів виступають тропеїчні структури (метафори, персоніфікації, епітети, порівняльні конструкції, перифрази) й стилістичні фігури (антитези, оксиморони, парадокси, парономазії, римування, замовчування, риторичні запи- тання), які забезпечують розширення смислових рамок повідомлення, розкривають його глибинні сутнісні ознаки. Вони концентрують імпліцитні змістові ракурси, формуючи психологічний заряд інформаційних найменувань.

Експериментальним матеріалом (результатами анкетування) підтверджено, що саме стилістично марковані медіазаголовки, вербалізовані тропофігуральними конструкціями, привертають увагу реципієнтів, мотивують до прочитання тексту.

\section{СПИСОК ВИКОРИСТАНИХ ДЖЕРЕЛ}

1. Белянин В. П. Основы психолингвистической диагностики. (Модели мира в литературе). Москва : Тривола, 2000. $248 \mathrm{c}$.

2. Булах М. Б. Психолінгвістична аспектологія аналізу перифраз у медіа. Актуальні проблеми украӥнської лінгвістики: теорія і практика. Київ, 2015. № 31. С. 57-69.

3. Великий тлумачний словник сучасної української мови / уклад. і голов. ред. В. Т. Бусел. Київ; Ірпінь : ВТФ «Перун», 2005. 1728 с.

4. Залевская А. А. Психолингвистические исследования. Слово. Текст. Москва : «Гнозис», 2005.542 с.

5. Засєкіна Л. В., Засєкін С. В. Психолінгвістична діагностика. Луцьк : РВВ «Вежа» Волин. нац. ун-ту ім. Лесі Українки, 2008. 188 с.

6. Куранова С. І. Основи психолінгвістики. Київ : ВЦ «Академія», 2012. 208 с.

7. Леонтьев А. А. Основы психолингвистики. Москва : Смысл, 1997. 287 с.

8. Межов О. Г., Костусяк Н. М. Префіксальні інновації як засіб психологічного впливу на свідомість реципієнтів. Psycholinguistics. Психолінгвістика. Психолингвистика. Переяслав-Хмельницький, 2008. Вип. 24 (2). С. $97-113$.

9. Навальна М. І. Пейоративи в мові української періодики. Psycholinguistics. Психолінгвістика. Психолингвистика. Переяслав-Хмельницький, 2017. Вип. 22 (2). С. 85-97.

10. Психологічний словник / авт.-уклад.: В. В. Синявський, О. П. Сергєєнкова. Київ : Науковий світ, 2007. URL: http://elibrary.kubg.edu.ua/id/eprint/5980/3/O Serhieienkova IL.pdf.

11. Селіванова О. О. Сучасна лінгвістика: напрями і проблеми. Полтава : Довкілля-К, 2008. 712 с.

12. Сизонов Д. Ю. Психолінгвістичні основи медіаграмотності: до проблеми інтерпретації медіатекстів. Science and education. Наука і освіта. Одеса, 2017. № 7. С. 82-88.

13. Стехіна В. М. Парадокси як мовна гра в сучасних медіатекстах. Теле- та радіожурналістика. Львів, 2010. Вип. 9 (2). С. 336-341.

14. Холод О. М. Соціальні комунікації: соціо- і психолінгвістичний аналіз. Львів : ПАІС, 2011. 288 с.

15. ЯцимірськаМ.Г.,ДраганН.В.Медіатекст якпродуктжурналістськоїтворчості(психолінгвістичнийаналізлогічного сприйняття та емоцій). Вісник Львівського університету. Серія журналістика. Львів, 2007. Вип. 30. С. $267-276$.

16. Borbely A. F. Psychoanalytic Concept of Metaphor. International Journal of Psycho-Analysis. 1998. No. 78. P. $923-936$.

17. Gibbs R. W. Jr. Psycholinguistic comments on metaphor identification. Language and Literature. 2002. No. 11 (1). P. $78-84$

\section{REFERENCES}

1. Beljanin V. P. Osnovy psiholingvisticheskoj diagnostiki. (Modeli mira v literature) [Fundamentals of psycholinguistic diagnosis. (Models of the world in literature)]. Moskva : Trivola, 2000. 248 s. [in Russian].

2. Bulakh M. B. Psykholinhvistychna aspektolohiia analizu peryfraz u media [Psycholinguistic aspectology of analysis of periphrases in media]. Aktualni problemy ukrainskoi linhvistyky: teoriia i praktyka. Kyiv, 2015. № 31. S. 57-69 [in Ukrainian].

3. Velykyi tlumachnyi slovnyk suchasnoi ukrainskoi movy [Big explanatory dictionary of modern Ukrainian language] / uklad. i holov. red. V. T. Busel. Kyiv; Irpin : VTF „Perun”, 2005. 1728 s. [in Ukrainian].

4. Zalevskaja A. A. Psiholingvisticheskie issledovanija. Slovo. Tekst [Psycholinguistic researches. Word. Text]. Moskva : „Gnozis”, 2005. 542 s. [in Russian].

5. Zasiekina L. V., Zasiekin S. V. Psykholinhvistychna diahnostyka [Psycholinguistic diagnostics]. Lutsk : RVV „Vezha” Volyn. nats. un-tu im. Lesi Ukrainky, 2008. 188 s. [in Ukrainian].

6. Kuranova S. I. Osnovy psykholinhvistyky [Fundamentals of Psycholinguistics]. Kyiv : VTs „Akademiia”, 2012.208 s. [in Ukrainian].

7. Leont'ev A. A. Osnovy psiholingvistiki [Fundamentals of Psycholinguistics]. Moskva : Smysl, 1997.287 s. [in Russian].

8. Mezhov O., Kostusiak, N. Prefiksalni innovatsii yak zasib psykholohichnoho vplyvu na svidomist retsypiientiv [Prefixal Innovations as a Mean of Psychological Impact on Consciousness Ofrecipient]. Psycholinguistics. Psykholinhvistyka. Psykholynhvystyka. Pereiaslav-Khmelnytskyi, 2008. Vyp. 24(2). S. 97-113 [in Ukrainian].

9. Navalna M. Peioratyvy v movi ukrainskoi periodyky [Pejoratives in Language of Ukrainian Periodicals]. Psycholinguistics. Psykholinhvistyka. Psykholynhvystyka. Pereiaslav-Khmelnytskyi, 2017. Vyp. 22 (2). S. $85-97$ [in Ukrainian]. 
10. Selivanova O. O. Suchasna linhvistyka: napriamy i problemy [Modern linguistics: directions and problems]. Poltava : Dovkillia-K, 2008. 712 s. [in Ukrainian].

11. Syzonov D. Yu. Psykholinhvistychni osnovy mediahramotnosti: do problemy interpretatsii mediatekstiv [Psycholinguistic bases of media literacy: considering the issue of media texts interpretation]. Science and Education. Nauka i osvita. Odesa, 2017. № 7. S. 82-88 [in Ukrainian].

12. Psykholohichnyi slovnyk [Psychological Dictionary] / avt.-uklad.: V. V. Syniavskyi, O. P. Serhieienkova. Kyiv : Naukovyi svit, 2007. URL: http://elibrary.kubg.edu.ua/id/eprint/5980/3/O_Serhieienkova_IL.pdf [in Ukrainian].

13. Stekhina V. M. Paradoksy yak movna hra v suchasnykh mediatekstakh [Paradoxes as linguistic game in modern mediatexts]. Tele- ta radiozhurnalistyka. Lviv, 2010. Vyp. 9(2). S. 336-341 [in Ukrainian].

14. Kholod O. M. Sotsialni komunikatsii: sotsio- i psykholinhvistychnyi analiz [Social communications: social and psycholinguistic analysis]. Lviv : PAIS, 2011. 288 s. [in Ukrainian].

15. Yatsymirska M., Drahan N. Mediatekst yak produkt zhurnalistskoi tvorchosti (psykholinhvistychnyi analiz lohichnoho spryiniattia ta emotsii) [Media text as a result of journalistic creativity (psycholinguistic analysis of logical perception and emotion)]. Visnyk Lvivskoho universytetu. Seriia zhurnalistyka. Lviv, 2007. Vyp. 30. S. 267-276 [in Ukrainian].

16. Borbely A. F. Psychoanalytic Concept of Metaphor. International Journal of Psycho-Analysis. 1998. No. 78. Pp. 923-936 [in English].

17. Gibbs R. W. Jr. Psycholinguistic comments on metaphor identification. Language and Literature. 2002. No. 11 (1). Pp. 78-84 [in English]. 